\title{
植物与传粉者地理镶嵌的协同演化: 过程、证据与展望
}

\author{
王晓月 ${ }^{1}$, 汤晓辛 ${ }^{1}$, 童泽宇 ${ }^{2}$, 黄双全 $^{2^{*}}$
}

1. 国家林业与草原局西南喀斯特山地生物多样性保护重点实验室, 贵州省植物生理与发育调控重点实验室, 贵州师范大学生命科学学院, 贵阳 550025;

2. 华中师范大学生命科学学院进化与生态学研究所, 武汉 430079

*联系人, E-mail: hsq@mail.ccnu.edu.cn

2018-12-06 收稿, 2019-01-07 修回, 2019-01-08 接受, 2019-02-21 网络版发表

贵州省科技厅2019年基础研究计划、贵州师范大学博士科研启动经费(11904/0518046)和国家自然科学基金(31730012, 31560184, 31300317)资助

摘要 协同演化是两个或更多互作物种间, 因交互选择导致特征发生交互式的演化转变. 地理镶嵌的协同演化理 论认为, 成对协同演化发生在不同的地理环境水平上. 对植物与传粉者而言, 地理镶嵌式的协同演化是指在不同地 方的植物, 其传粉者的不同导致了植物花部特征的分化, 也被称为传粉生态型. 对传粉生态型概念的研究多集中在 不同的海拔以及生境传粉者体型、传粉者功能群与植物花部特征或花报酬的协同演化. 总结近年来的研究, 可将 植物与传粉者地理镶嵌的协同演化的形式归纳为 5 类: 花形态、花结构、花颜色、花气味信号成分、花报酬与传 粉者的种类或者体型的协同演化关系。未来在研究植物与传粉者地理镶嵌的协同演化时, 不仅要关注植物与传粉 者特性本身, 还应关注非生物环境因子. 高通量基因测序以及新的分析手段的引入, 可进一步推进植物与传粉者的 地理镶嵌的协同演化研究.

关键词 协同演化, 地理镶嵌的协同演化, 传粉生态型, 多样化, 植物-传粉者相互作用

\section{1 协同演化}

协同演化(coevolution)是两个或更多互作物种间， 因交互选择导致特征发生交互式的演化转变 ${ }^{[1]}$. 协同演 化概念的形成最早可追溯到达尔文 ${ }^{[2]}$ 提出的协同适应 (coadaptation). 协同演化概念的正式提出归功于Ehrlich 和 Raven ${ }^{[3]}$, 他们从演化的视角探讨植物有毒次级代谢 产物与菜粉蝶耐毒性的“军备竞赛”. 近年来发展起来 的地理镶嵌协同演化理论, 使协同演化理论研究得到 更多的关注 ${ }^{[4-6]}$.

大部分的物种都面临着与其他物种相互作用、演 化、协同演化的局面. 诠释物种是如何应对这些局面 是生态学和进化生物学最基本的问题之一, 因为它连 接着生物多样性进化上 3 个重要的问题: 物种的多样
性、物种间分化的多样性，以及物种形成生态群落的 方式的多样性. 互作类群之间的协同演化是地球生命 多样化的一个重要原因 ${ }^{[6-11]}$.

\section{2 地理镶嵌的协同演化理论的主要观点}

为了强调种群级别的时间和空间尺度上异质性的 广泛性和重要性, Thompson ${ }^{[4,5,12]}$ 提出了地理镶嵌的协 同演化(geographic mosaic theory of coevolution, GMC), 并提供可供检测的协同演化假说. 地理镶嵌的 协同演化理论, 有益于人们理解自然选择和协同演化 过程在居群之间的差异 ${ }^{[5]}$.

地理镶嵌的协同演化理论认为，时间和空间作用 决定了协同演化相互作用的结果. 成对物种或者成群 物种协同演化动态发生在不同的地理环境水平上，而

引用格式: 王晓月, 汤晓辛, 童泽宇, 等. 植物与传粉者地理镶嵌的协同演化: 过程、证据与展望. 科学通报, 2019, 64: 1702-1710 Wang X Y, Tang X X, Tong Z Y, et al. Geographic mosaic theory of coevolution in plant and pollinator interaction: Process, evidence, prospect (in Chinese) Chin Sci Bull, 2019, 64: 1702-1710, doi: 10.1360/N972018-01213 
不是在当地居群水平上 ${ }^{[4,5,12]}$. 该理论主要包括3个内 容: (1) 居群间选择的力度和方向是一个过程(即选择 镶嵌). 自然选择在居群间是变化的, 一个物种由于另 外一个物种在不同居群基因型分布不同，导致其适合 度的地理差异, 即基因型-基因型-环境(genotype-bygenotype-by-environment，G-G-E)的相互作用. (2) 协 同演化热点地区(hotspot)和冷点地区(coldspot)混合分 布. 热点地区是确实发生协同演化选择的地区, 冷点地 区是几乎不发生或完全不发生协同演化选择的地区， 这是因为互作物种的特征在一些群落中匹配得很好 (即协同演化热点), 而在其他群落中则匹配得不够好 (即协同演化冷点), 亦即适应(adaptation)和不适应(maladaptation $)^{[13]}$. 例如, 十字花科的Erysimum mediohispanicum 在美国内华达山脉的分布存在热点地区和冷 点地区, 其中, 在热点地区的个体花柄短、花小、花冠 管长且狭窄, 与传粉者蜂类协同演化; 而在冷点地区的 个体花冠管宽, 与传粉甲虫和蝇类在结构上不匹配, 几 乎不发生协同演化 ${ }^{[14]}$. (3) 由于选择作用的地理镶嵌、 协同演化的热点地区和冷点地区的混合分布、基因漂 变和基因流等因素, 物种的特征在不同的地理环境中 持续性地混合 ${ }^{[5,15]}$.

地理镶嵌的协同演化会导致生态上的 3 个型式: (1) 由于互作对象或者程度的不同，同一物种在不同居群 特征会不一致. 例如, 分布在森林居群的兰科二叶舌唇 兰Platanthera bifolia, 传粉者主要是长吻的天蛾Sphinx ligustri, 其花大、花蜜距长; 而分布在草地居群的传粉 者多为短吻的天蛾Deilephila porcellus, 其花小、花蜜 距短 ${ }^{[16]}$. (2) 存在互作物种特征相匹配的居群(热点地 区)和特征不匹配的居群(冷点地区). 例如，交喙鸟 (crossbills)和松柏科的球果在缺乏松鼠的居群(协同演 化的热点地区)存在特征的“军备竞赛”, 在这些居群, 交 㗒鸟演化出更厚、更短、更卷曲的㖨以便于取食更 大、球鳞更厚的球果; 然而，在松鼠存在的居群(协同 演化的冷点地区), 交㗒鸟和球果的特征之间几乎不存 在“军备竞赛, ${ }^{\text {[17] }}$. (3) 一些物种水平上协同演化的特征 可能会扩散到整个居群. 例如, 虎耳草科林星花属 (Lithophragma)系统发生的分析表明, L. parviflorum特 化的柱头、深的花冠、无气味可能是潜在的、会扩散 到整个居群的、物种水平上的协同演化的特征 ${ }^{[4,18]}$.

\section{3 植物与传粉者的协同演化}

植物与传粉者之间是经典的互惠关系. 据估计, 地
球上 $87.5 \%$ 的开花植物依赖动物传粉而受精结实 ${ }^{[19]}$. 传 粉者介导的选择作用是被子植物多样性的关键性的进 化力量之一 ${ }^{[20,21]}$. 植物与传粉者的相互作用经历了漫 长的演化, 化石资料表明, 某些昆虫(蝇类和甲虫)在被 子植物起源后, 物种分化速率加快 ${ }^{[22,23]}$.

最有效传粉者假说认为, 当地最频繁的、最有效 的传粉者可能对植物的特征(大小、颜色、气味、花 序的高度), 以及一些动植物相互作用机械匹配(mechanical fit, 即植物花与动物的传粉器官在形态结构上 的匹配, 如花冠管长与吻长)的特征有选择作用 ${ }^{[24 ~ 26]}$. 反过来，花部特征也会对传粉者的特征起到选择作用， 形成互惠的协同演化 ${ }^{[27,28]}$. 植物与传粉者特征的匹配 一直都是解释物种之间协同演化的有力证据 ${ }^{[20,28-30]}$.

植物的花结构与颜色适应于不同种类的有效的传 粉者, 而传粉者也发生相应的适应性改变 ${ }^{[21]}$. 例如, 茄 科Iochrominae 亚族中管状花主要由蜂鸟传粉, 而开放 型的花(杯状或者钟状)主要由昆虫传粉 ${ }^{[31]}$. 蓝色和紫 色的花通常由熊蜂访问, 因为熊蜂的视觉在紫外、 蓝、绿 3 个波长存在敏感区 ${ }^{[32,33]}$. 红色的花通常由鸟类 访问, 因为鸟类有很好的视觉辨别能力 ${ }^{[34]}$. 植物花蜜的 特征, 例如糖的组成、糖浓度、花蜜体积、蔗糖-己糖 的比例、花蜜的分泌动态等, 与传粉者的特性密切相 关 ${ }^{[35,36]}$. 例如, 在玄参科钓钟柳属(Penstemon)中, 花蜜 量大、花蜜糖浓度低、花蜜蔗糖-已糖比例高的物种 更受鸟类的访问偏好 ${ }^{[34]}$. 植物花气味特征与植物-传粉 者协同演化关系也十分密切. 不同的植物种可能含有 相同或者功能相似的花气味成分，从而可能吸引同一

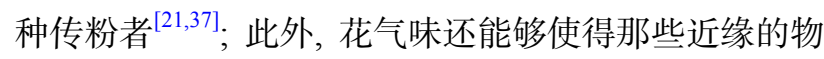
种在传粉系统上发生改变, 例如, 在透骨草科沟酸浆属 (Mimulus) 中, 一些物种由蜂类传粉, 而另一些物种由蜂 鸟传粉 ${ }^{[38]}$.

传粉者的特征可适应于植物传粉并发生演化, 例 如, 蜂类体表的毛或毛区适合于黏附花粉, 从而有利于 植物花粉的传递 ${ }^{[39,40] ;}$ 长吻的蝇类和蛾类适合给长花 冠管或者花蜜距的植物传粉 ${ }^{[41,42] ;}$ 为有毒植物传粉的 昆虫通常对植物产生的有毒次级代谢物质有抗 性 $^{[43 \sim 45]}$.

除了单纯的互惠关系，一些昆虫在为植物提供传 粉服务的同时, 其幼虫还会以植物的器官为食. 这种现 象在许多类群中均有报道, 如榕树和榕小蜂 ${ }^{[46,47]}$, 丝兰 和丝兰蛾 ${ }^{[48,49]}$, 虎耳草属植物和Greya 蛾 ${ }^{[6]}$, 金莲花和金 莲花蝇类 ${ }^{[50]}$ 等. 


\section{4 植物与传粉者地理镶嵌的协同演化}

对植物与传粉者地理镶嵌的协同演化的研究由来 已久, 人们已积累大量的实证. Grant和Grant ${ }^{[51]}$, Steb$\operatorname{bins}^{[24]}$ 提出花形态的分化跟地理上传粉者的镶嵌分布 有关, 是对当地最有效传粉者的适应, 传粉者的地理镶 嵌式组分可以产生纵贯植物居群的地理上的歧化选择. 地理上传粉者的不同导致植物居群的花部特征的分化, 这一现象也被称作传粉生态型(pollination ecotype $)^{[26,29,52,53]}$.

一般来说, 地理上分布广泛的植物, 都可能面临复 杂的镶嵌式的传粉者 ${ }^{[54 ~ 57]}$. 居群间传粉者介导的对花 型的选择强度也是多变的, 会导致花部特征在地理上 的变异, 包含花期物候 ${ }^{[58]}$ 和花形态的变异 ${ }^{[59 \sim 62]}$. 在不 同的地理环境, 同一种传粉者, 其形态 ${ }^{[26,63]}$ 或行为 ${ }^{[64]}$ 存 在差异，可能是适应于不同地理居群植物花部特征的 变异. 例如，互补特征的协同演化所导致的竞赛升级 (escalation), 驱动了昆虫口器和花冠管长度的异域分 化 ${ }^{[28,41,42]}$. Anderson和Johnson以一种长吻的蝇类Prosoeca ganglbaueri及其主要的食源性植物玄参科Zaluzianskya microsiphon为研究对象, 调查了它们的分布 区域, 发现植物花冠管长和传粉者吻长在不同居群变 异很大, 但是两者是高度正相关, 体现出典型地理镶嵌 的样式 ${ }^{[41]}$.

具体而言, 植物与传粉者彼此施加选择压力, 影响 花部特征与传粉者身体的特征的分化, 且传粉者往往 通过行为偏好或者通过形态上的机械匹配来选择花部 特征 ${ }^{[30,65,66]}$.

\section{1 地理镶嵌型式: 花形态}

处于不同地理环境, 如不同的海拔和生境, 传粉者 存在差异, 多样的传粉者可能对植物花部特征的分化 有选择作用 ${ }^{[6,52,53,67,68]}$. 目前, 许多实地证据表明, 花形 态在地理上的变异，常常与传粉者在地理上的不同相 关 $^{[69,70]}$.

花形态上的地理变异，反映了传粉者的地理变异， 以及相关选择压力的歧化变异. 例如, Newman等人 ${ }^{[26]}$ 发现石蒜科Nerine humilis花部特征在不同的地理居群 的变异, 是适应当地不同传粉者. Thompson等人 ${ }^{[71]}$ 对 虎耳草科林星花属(Lithophragma)的6种石篱(woodland star)花形态的变异与其丝兰蛾科Greya传粉者关系的研 究, 表明6种石篱之间的形态差异, 取决于各物种在本
土与多少种传粉蛾类发生互作. 与此同时, Greya属两 种蛾子的形态也有明显的地理歧化，且这种歧化取决 于当地宿主植物的种类，以及当地是否有其他互作的 蛾类.

分布于西班牙中部瓜达拉马山脉不同海拔 (680 1300 m)11个居群的豆科金雀儿Cytisus scoparius, 在传粉者体型更大的居群，有更大的花 ${ }^{[67]}$. Sun ${ }^{[72]}$ 对中 国庐山、新宁和神农架3个不同的生境，12个居群的独 花兰Changnienia amoena形态变异的研究表明, 神农架 地区龙门河和关门山独花兰形态有差异, 且当地主要 传粉者分别是 3 条熊蜂Bombus trifasciatus 和仿熊蜂B. imitator，而两种熊蜂在个体大小和受食行为上有显著 差异. Medel等人 ${ }^{[73]}$ 发现智利中部透骨草科Mimulus $l u$ teus 花形态的地理变异主要是由于传粉者的不同, 对7 个居群花冠和蜜导的大小的测量表明，花冠大小随着 蜂类在传粉者中的组分增加而增大，而随着鳞翅目昆 虫的减少而减小; 花蜜导大小随着蜂鸟占比的提升而 增大. 毛茛科毛莨状金莲花Trollius ranunculoides分布 于中国甘肃省合作县亚高山居群的个体花瓣数目少、 花较大, 主要由蜂类访问, 而分布于玛曲县高山居群的 个体，花瓣多、花更小，主要由蝇类访问 ${ }^{[74]}$. 随着海拔 的改变, 居群中唇形科Prunella vulgaris的花部特征和 传粉熊蜂的身体结构发生歧化，且花冠长度与本土熊 蜂体型大小呈现出强烈的正相关 ${ }^{[75]}$.

\section{2 地理镶嵌型式: 花结构(管长、蜜距长)}

花结构，尤其是花报酬存储器官(即花冠管长或者 花蜜距长)，与传粉者身体结构，如吻长或足长之间存 在的地理镶嵌的协同演化，是植物与传粉者机械匹配 研究的焦点 ${ }^{[28,30]}$. Darwin ${ }^{[20]}$ 曾提出, 马达加斯加岛彗星 兰Angraecum sesquipedale长花蜜距是与一种长吻的天 蛾协同适应的结果. 人们根据达尔文的假说, 提出自然 选择会使传粉者的吻长演化得更长从而便于取食花蜜, 而自然选择也会使植物演化出更长的花冠管使传粉者 能够和繁殖器官相接触而使花粉的传递最大化 ${ }^{[20,27]}$. 这 种选择将会导致花冠管长和传粉者吻长之间的军备竞 赛 ${ }^{[6,41]}$.

作为研究协同演化研究的模式特征，花冠管长和 传粉者吻长之间的互作得到广泛的研究 ${ }^{[76]}$. Pauw等 人 ${ }^{[28]}$ 对南非不同地理环境9个居群的调查发现，长吻蝇 Moegistorhynchus longirostris的吻长和㖊尾科Lapeirousia anceps 花冠管长是显著正相关的. Anderson等人 ${ }^{[30]}$ 
探讨天蛾与非洲或尾Gladiolus longicollis之间的传粉 关系，不同的地理居群G. longicollis的花冠管长度在 35 130 mm之间变异, 且呈双峰分布(两个峰值分别大 约是 50 和 $90 \mathrm{~mm}$ ), 相应地, 非洲东部分布的天蛾舌长也 呈相应的双峰分布. 分布在尼泊尔不同居群的高原姜 科植物紫花象牙参Roscoea purpurea花冠管长存在变 异，其传粉者虹科蝇类Philoliche longirostris的吻长在 不同居群也存在变异，且花冠管长与吻长在居群之间 显著正相关 ${ }^{[42]}$.

地理镶嵌式的植物花蜜距长度变异与传粉者种类 或者体型的机械匹配是协同演化另一个研究焦点. 如, 兰科舌唇兰属的一种黄玉凤花Platanthera ciliaris主要 由蝴蝶传粉, 沿海平原地区主要的传粉蝶类Papilio palamedes的吻长显著短于分布在高山地区的蝶类 $P$. troi$l u s$, 而分布在沿海平原的 P. ciliaris的花蜜距也显著短 于分布在高山地区的个体的花蜜距 ${ }^{[52]}$. 南美洲热带雨 林的玄参科Diascia属物种的花蜜距的长度变异很 大 $^{[77]}$, 而其主要的传粉者准蜜蜂科Rediviva neliana的前 足以及身体大小在不同的居群间有很大的变异. 调查 表明南非 22 个居群的Diascia物种的花蜜距长度和相应 传粉昆虫 $R$. neliana 的前足长度是极显著正相关的 ${ }^{[78]}$.

\section{3 地理镶嵌型式: 花颜色}

花颜色和传粉者视觉的适应，为地理镶嵌的协同 演化提供例证 ${ }^{[56,79]}$. 分布于挪威的多种高山植物在低 海拔居群的传粉者以蜂类为主，在高海拔居群的传粉 者以蝇类为主; 相应地，随着海拔的升高，植物的花色 由适应于蜂类视觉的蓝色和紫外蓝转变为适应于蝇类 视觉的蓝-绿色和绿色 ${ }^{[80]}$. 紫外反射(ultraviolet, UV)也 是花色的组分, 蓄薇科Argentina anserina花的紫外反射 的环纹圈(bullseye pattern)大小随着海拔的提升而增大. 相应地, 传粉者以膜翅目为主转变为以双翅目为主 导 $^{[81]}$.

\section{4 地理镶嵌型式: 花气味信号}

传统的植物与传粉者协同演化的研究多集中在形 态上的协同适应. 近年来, 植物花气味信号与传粉者响 应之间的地理匹配引起了人们的重视. 高海拔居群的 花苾科Polemonium viscosum花冠较大，散发甜香的气 味，由熊蜂传粉; 而分布在林下的个体，花冠较小，从 花蕶处散发“臭鼠”般的气味，主要由蝇类和小型蜂类 传粉 ${ }^{[82]}$. Suinyuy等人 ${ }^{[83]}$ 对苏铁科 Encephalartos villosus
的研究也提供很好的例证. 苏铁的传粉系统是巢穴寄 生互惠，即传粉者和昆虫啃食者的幼虫以雄球花组织 为食, 雄球花为成虫以及幼虫提供食物(花粉), 而䧳球 花通过释放相同的气味吸引传粉者而完成授粉 ${ }^{[84]}$. 非 洲苏铁E. villosus的球花气味混合物有明显的地理变 异. 不同的分布区域的E. villosus由同种甲虫传粉，在 较为北部的居群, 球花释放的主要是烯烃类, 而南部的 居群主要释放单萜和吡嗪混合物; 在交互选择实验中, 甲虫偏好选择本土区域球花释放的气味，来自北部居 群的甲虫的触角反应主要响应烯烃类，而南部居群的 甲虫触角反应主要响应吡嗪. 另外一种非洲苏铁 $E$. ghellinckii, 分布在德拉肯斯堡山的球花主要释放 cis- $\beta$ 罗勒烯、 $\beta$-月桂烯和(3E)-1,3-辛二烯，分布在近海岸线 居群的球花主要释放茨烯和 $\alpha$-松萜. 研究表明这些气 味成分的差别响应了各地不同的甲虫类群 ${ }^{[85]}$.

\section{5 地理镶嵌型式: 花报酬}

同种植物在不同居群，花报酬产量、类型跟传粉 者之间也可发生地理镶嵌的协同演化. 位于阿根廷北 部的多肉植物仙人掌科光虹丸Echinopsis ancistrophora 可由隧蜂和天蛾传粉, 个体花冠管短、花药早上 开裂、花蜜量少的光虹丸, 主要由当地的隧蜂传粉; 花 冠管长、花药黄昏时期开裂、花蜜量大的光虹丸由当 地的天蛾传粉 ${ }^{[68]}$. Gowda和Kress ${ }^{[86]}$ 通过调查开花式 样、花蜜特性和蜂鸟的访问频率与以地理变异之间的 关联，探讨了东部加勒比海岛屿上的植物-传粉者互作 关系的地理镶嵌模式，发现不同岛屿之间主要的植物 物种不一样，且植物物种之间和不同岛屿之间的植物 花蜜产量有显著差异，而蜂鸟的主要访问样式在岛屿 之间也不一致，且高度多变. 车前科Monttea aphylla同 时给传粉者提供油滴和花蜜两种报酬，对分布于阿根 廷的蒙特沙漠 16 个居群的研究表明，北部居群的更偏 好产生油滴，而两个中部以及南部地区居群更倾向于 产生花蜜作为报酬; 随着纬度越高, 特化取食花蜜并且 传粉的蜂类Centris vardyorum的分布数量越多, 而当地 居群的花蜜分泌量也逐渐增大 ${ }^{[87]}$.

\section{5 地理镶嵌的协同演化理论在植物-传粉者 互作中的验证方法}

有研究认为, 从交互式(协同演化热点)转变到非交 互式冷点 ${ }^{[13]}$ 可以在时间和空间上发生改变. 然而, 这种 观点仍需要更多的多居群研究加以验证. 另外, 协同演 
化的进程也会受非生物环境所影响，因而在考虑特征 演化的时候, 很有必要考虑多重的生态因子.

Newman等人 ${ }^{[26]}$ 最近采用的方法值得借鉴, 其验证 思路是: (1) 检测花部特征和传粉者之间的关联，包括 花部特征与传粉者种类的关联，以及花部特征与传粉 者虫体长度的关联; (2) 交互的移栽实验以检测当地表 型与移栽表型之间结实率的差异; (3) 单次访问实验, 以检测当地表型和引人表型花粉输出方面的差异. 这 种递进的方法是为验证传粉者访问的有效性是否取决 于花与访问者之间的机械匹配，并最终提供证据以验 证花部特征在居群间的变异是否是传粉者地理变异的 选择所致.

上述地理镶嵌的植物与传粉者协同演化的验证方 法，在定义植物在不同居群出现变异的原因可能面临 一个问题: 植物花部特征的分化可能受多重因子的选 择作用, 不仅仅跟一个生态学因素的转变有关, 例如可 能与生境的类型以及传粉者的转变都有关. 实验演化 生物学的研究有助于解决这个问题. 最近Gervasi和 Schiestl ${ }^{[88]}$ 对来自同一居群的十字花科植物Brassica rapa构建了植物家系, 分别用熊蜂、食蚜蝇以及人工 操作进行授粉, 进行连续9代的培养. 结果表明, 由熊蜂 传粉的个体的后代植株更高, 气味更加浓郁, 更加吸引 熊蜂传粉; 而食蚵蝇授粉的个体的后代更加趋于自动 自花授粉. 这项研究不仅说明植物的变异跟传粉者的 分化相关，同时使人们意识到传粉者数量的减少或者 丢失将影响演化的结果.

目前, 高通量基因测序技术日渐成熟, 基因检测已 经成为确定生态分化以及物种形成有关的基因区域的 最常用的手段. 物种形成过程中全基因组的分化形式 是目前的一个研究热点. 离群值扫描(outlier scan)和地 理渐变群分析(geographic cline analysis)可以用于分析 传粉生态型不同表型间全基因组的分化 ${ }^{[89]}$. 离群值扫 描可以产生群落成千上百万基因位点的数据, 反映了 类群间全基因组分化的高度复杂性 ${ }^{[90,91]}$. 如果高度分 化的离群值的位点与导致居群间基因流的分化选择和 阻碍的基因区域是相关的 ${ }^{[92]}$ ，可以用来分析不同地理 分布上植物特征差异的分子机理. 渐变群分析可以比 较杂交群基因流阻碍的本质和力度，更可以用来检测 等位基因频率差异的空间因素 ${ }^{[93,94]}$, 而且, 在这一框架 中, 数据可以定量, 分子标记渐变群分析可以直接比较 渐变群的表型特征或者环境的变化, 为分析生态学的 差异提供进一步的证据 ${ }^{[95,96]}$.

\section{6 结语}

地理镶嵌的协同演化理论认为时间和空间作用影 响了协同演化相互作用的结果. 地理上传粉者的不同 导致了植物的特征的分化, 表现出传粉生态型. 对植物 与传粉者地理镶嵌的协同演化验证集中在不同的地理 居群植物花形态、结构、颜色和报酬，与传粉者的种 类以及体型差异的协同演化.

未来的研究应进一步检验该理论的普遍性和重要 性, 以及在地方适应性和生殖隔离上的作用, 例如传粉 者与花粉、花蜜等植物特征的相互作用是如何影响 传粉以及生殖成功、传粉者的不同是如何与有关的 植物特征关联、有关的特征又是如何被不同的传粉 者选择的. 具体的研究内容应不仅包括各种生物的因 子，还需涵盖非生物的因子，非生物的因子也会导致 不同地理区域特征的变化，可能包括气候的变量、其 他生态学的相互作用、居群所在地区土地使用的变 化等.

\section{致谢感谢华中师范大学熊英泽博士、吴凌云博士和贵州师范大学唐明副教授提供的有益建议.}

\section{参考文献}

1 Althoff D M, Segraves K A, Johnson M T J. Testing for coevolutionary diversification: Linking pattern with process. Trends Ecol Evol, 2014, 29: $82-89$

2 Darwin C. On the Origin of Species: A Facsimile of the First Edition with an Introduction by Ernst Mayr. Cambridge: Harvard University Press, 1964

3 Ehrlich P R, Raven P H. Butterflies and plants: A study in coevolution. Evolution, 1964, 18: 586-608

4 Thompson J N. The Coevolutionary Process. Chicago: The University of Chicago Press, 1994

5 Thompson J N. The Geographic Mosaic of Coevolution. Chicago: The University of Chicago Press, 2005

6 Thompson J N, Schwind C, Guimarães P R, et al. Diversification through multitrait evolution in a coevolving interaction. Proc Natl Acad Sci USA, 2013, 110: 11487-11492 
7 Schluter D. The Ecology of Adaptive Radiation. Oxford: Oxford University Press, 2000

8 Dietl G P, Kelley P H. The fossil record of predator-prey arms races: Coevolution and escalation hypotheses. Paleontol Soc Pap, 2002, 8: 353-374

9 Jablonski D. Biotic interactions and macroevolution: Extensions and mismatches across scales and levels. Evolution, 2008, 62: 715-739

10 Futuyma D J, Agrawal A A. Macroevolution and the biological diversity of plants and herbivores. Proc Natl Acad Sci USA, 2009, 106: 1805418061

11 Janz N. Ehrlich and Raven revisited: Mechanisms underlying codiversification of plants and enemies. Annu Rev Ecol Evol Syst, 2011, 42: 71-89

12 Thompson J N. Specific hypotheses on the geographic mosaic of coevolution. Am Nat, 1999, 153: S1-S14

13 Gomulkiewicz R, Thompson J N, Holt R D, et al. Hot spots, cold spots, and the geographic mosaic theory of coevolution. Am Nat, 2000, 156: 156174

14 Gómez J M, Abdelaziz M, Camacho J P M, et al. Local adaptation and maladaptation to pollinators in a generalist geographic mosaic. Ecol Lett, 2009, 12: 672-682

15 Thompson J N, Cunningham B M. Geographic structure and dynamics of coevolutionary selection. Nature, 2002, 417: 735-738

16 Boberg E, Alexandersson R, Jonsson M, et al. Pollinator shifts and the evolution of spur length in the moth-pollinated orchid Platanthera bifolia. Ann Bot, 2014, 113: 267-275

17 Benkman C W, Parchman T L, Favis A, et al. Reciprocal selection causes a coevolutionary arms race between crossbills and lodgepole pine. Am Natist, 2003, 162: 182-194

18 Davis D R, Pellmyr O, Thompson J N. Biology and Systematics of Greya Busck and Tetragma, New Genus (Lepidoptera: Prodoxidae). Washington DC: Smithsonian Institution Press, 1992

19 Ollerton J, Winfree R, Tarrant S. How many flowering plants are pollinated by animals? Oikos, 2011, 120: 321-326

20 Darwin C. On the Various Contrivances by Which British and Foreign Orchids are Fertilised by Insects. Cambridge: Cambridge Library Collection, 1862

21 Fenster C B, Armbruster W S, Wilson P, et al. Pollination syndromes and floral specialization. Annu Rev Ecol Evol Syst, 2004, 35: 375-403

22 Crepet W L. The role of insect pollination in the evolution of angiosperms. In: Real L, ed. Pollination Biology. New York: Academic Press, 1983. $31-48$

23 Herrera C M, Pellmyr O. Plant-Animal Interactions: An Evolutionary Approach. Oxford: Blackwell Science, 2002

24 Stebbins G L. Adaptive radiation of reproductive characteristics in angiosperms, I: Pollination mechanisms. Annu Rev Ecol Syst, 1970, 1: 307-326

25 Anderson B, Ros P, Wiese T J, et al. Intraspecific divergence and convergence of floral tube length in specialized pollination interactions. Proc R Soc B-Biol Sci, 2014, 281: 20141420

26 Newman E, Manning J, Anderson B. Local adaptation: Mechanical fit between floral ecotypes of Nerine humilis (Amaryllidaceae) and pollinator communities. Evolution, 2015, 69: 2262-2275

27 Muchhala N, Thomson J D. Going to great lengths: Selection for long corolla tubes in an extremely specialized bat-flower mutualism. Proc R Soc B-Biol Sci, 2009, 276: 2147-2152

28 Pauw A, Stofberg J, Waterman R J. Flies and flowers in Darwin's Race. Evolution, 2009, 63: 268-279

29 Gómez J M, Abdelaziz M, Camacho J P M, et al. Local adaptation and maladaptation to pollinators in a generalist geographic mosaic. Ecol Lett, 2009, 12: 672-682

30 Anderson B, Alexandersson R, Johnson S D. Evolution and coexistence of pollination ecotypes in an African Gladiolus (Iridaceae). Evolution, 2010, 64: 960-972

31 Smith S D, Kriebel R. Convergent evolution of floral shape tied to pollinator shifts in Iochrominae (Solanaceae). Evolution, 2017, 72: 688-697

32 Backhaus W, Menzel R. Color distance derived from a receptor model of color vision in the honeybee. Biol Cybernetics, 1987, 55: 321-331

33 Jersáková J, Kindlmann P, Renner S S. Is the colour dimorphism in Dactylorhiza sambucina maintained by differential seed viability instead of frequency-dependent selection? Folia Geobot, 2006, 41: 61-76

34 Wilson P, Castellanos M C, Wolfe A D, et al. Shifts between bee and bird pollination in Penstemons. In: Waser N M, Ollerton J, eds. Plantpollinator Interactions: From Specialization to Generalization. Chicago: University of Chicago Press, 2006. 47-68

35 Baker H G, Baker I. Floral nectar constituents in relation to pollinator type. In: Jones C E, Little R J, eds. Handbook of Experimental Pollination Biology. New York: Van Nostrand Reinhold, 1983. 117-141

36 Galetto L, Bernardello G. Floral nectaries, nectar production dynamics and chemical composition in six Ipomoea species (Convolvulaceae) in relation to pollinators. Ann Bot, 2004, 94: 269-280

37 Dobson H E M, Arroyo J, Bergström G, et al. Interspecific variation in floral fragrances within the genus Narcissus (Amaryllidaceae). Biochem Systatics Ecol, 1997, 25: 685-706

38 Byers K J R P, Bradshaw H D, Riffell J A. Three floral volatiles contribute to differential pollinator attraction in monkeyflowers (Mimulus). J Exp Biol, 2014, 217: 614-623 
39 Corbet S A, Beament J, Eisikowitch D. Are electrostatic forces involved in pollen transfer? Plant Cell Environment, 1982, 5: 125-129

40 Armbruster W S. Evolution of floral form: Electrostatic forces, pollination, and adaptive compromise. New Phytol, 2001, 152: 181-183

41 Anderson B, Johnson S D. The geographical mosaic of coevolution in a plant-pollinator mutualism. Evolution, 2008, 62: 220-225

42 Paudel B R, Shrestha M, Burd M, et al. Coevolutionary elaboration of pollination-related traits in an alpine ginger (Roscoea purpurea) and a tabanid fly in the Nepalese Himalayas. New Phytol, 2016, 211: 1402-1411

43 Adler L S. The ecological significance of toxic nectar. Oikos, 2000, 91: 409-420

44 Singaravelan N, Nee'man G, Inbar M, et al. Feeding responses of free-flying honeybees to secondary compounds mimicking floral nectars. J Chem Ecol, 2005, 31: 2791-2804

45 Kessler D, Gase K, Baldwin I T. Field experiments with transformed plants reveal the sense of floral scents. Science, 2008, 321: 1200-1202

46 Bronstein J L, McKey D. The fig/pollinator mutualism: A model system for comparative biology. Experientia, 1989, 45: 601-604

47 Duthie A B, Nason J D. Plant connectivity underlies plant-pollinator-exploiter distributions in Ficus petiolaris and associated pollinating and nonpollinating fig wasps. Oikos, 2016, 125: 1597-1606

48 Addicott J F, Bronstein J, Kjelberg F. Evolution of mutualistic life-cycles: Yucca moths and fig wasps. In: Gilbert F, ed. Insect Life Cycles: Genetics, Evolution and Co-Ordination. London: Springer-Verlag, 1990. 143-161

49 Althoff D M. Specialization in the yucca-yucca moth obligate pollination mutualism: A role for antagonism? Am J Bot, 2016, 103: 1803-1809

50 Pellmyr O. The cost of mutualism: Interactions between Trollius europaeus and its pollinating parasites. Oecologia, 1989, 78: 53-59

51 Grant V, Grant K A. Flower Pollination in the Phlox Family. New York: Columbia University Press, 1965

52 Robertson J L, Wyatt R. Evidence for pollination ecotypes in the yellow-fringed orchid, Platanthera ciliaris. Evolution, 1990, 44: 121-133

53 Sun M, Gross K, Schiestl F P. Floral adaptation to local pollinator guilds in a terrestrial orchid. Ann Bot, 2014, 113: 289-300

54 Althoff D M, Segraves K A, Pellmyr O. Community context of an obligate mutualism: Pollinator and florivore effects on Yucca filamentosa. Ecology, 2005, 86: 905-913

55 Johnson S D. Pollinator driven speciation in plants. In: Harder L D, Barrett S C H, eds. Ecology and Evolution of Flowers. Oxford: Oxford University Press, 2006. 295-311

56 Whittall J B, Hodges S A. Pollinator shifts drive increasingly long nectar spurs in columbine flowers. Nature, 2007, 447: 706-709

57 Godsoe W, Yoder J B, Smith C I, et al. Coevolution and divergence in the Joshua tree/yucca moth mutualism. Am Natist, 2008, 171: 816-823

58 Olsson K, Ågren J. Latitudinal population differentiation in phenology, life history and flower morphology in the perennial herb Lythrum salicaria. J Evolary Biol, 2002, 15: 983-996

59 Schemske D W, Horvitz C C. Temporal variation in selection on a floral character. Evolution, 1989, 43: 461-465

60 Ehlers B K, Olesen J M, Ågren J. Floral morphology and reproductive success in the orchid Epipactis helleborine: Regional and local acrosshabitat variation. Plant Syst Evol, 2002, 236: 19-32

61 Rey P J, Herrera C M, Guitián J, et al. The geographic mosaic in predispersal interactions and selection on Helleborus foetidus (Ranunculaceae). J Evol Biol, 2006, 19: 21-34

62 Pérez-Barrales R, Arroyo J, Armbruster W S. Differences in pollinator faunas may generate geographic differences in floral morphology and integration in Narcissus papyraceus (Amaryllidaceae). Oikos, 2007, 116: 1904-1918

63 Anderson B, Johnson S D. Geographical covariation and local convergence of flower depth in a guild of fly-pollinated plants. New Phytol, 2009, 182: $533-540$

64 Newman E, Anderson B, Johnson S D. Flower colour adaptation in a mimetic orchid. Proc R Soc B-Biol Sci, 2012, 279: 2309-2313

65 Nattero J, Cocucci A A, Medel R. Pollinator-mediated selection in a specialized pollination system: Matches and mismatches across populations. J Evolary Biol, 2010, 23: 1957-1968

66 Van der Niet T, Peakall R, Johnson S D. Pollinator-driven ecological speciation in plants: New evidence and future perspectives. Ann Bot, 2014, 113: $199-212$

67 Malo J E, Baonza J. Are there predictable clines in plant-pollinator interactions along altitudinal gradients? The example of Cytisus scoparius L. Link in the Sierra de Guadarrama (Central Spain). Divers Distrib, 2002, 8: 365-371

68 Schlumpberger B O, Cocucci A A, Moré M, et al. Extreme variation in floral characters and its consequences for pollinator attraction among populations of an Andean cactus. Ann Bot, 2009, 103: 1489-1500

69 Boyd A E. Breeding system of Macromeria viridiflora (Boraginaceae) and geographic variation in pollinator assemblages. Am J Bot, 2004, 91: $1809-1813$

70 Muchhala N. Adaptive trade-off in floral morphology mediates specialization for flowers pollinated by bats and hummingbirds. Am Nat, 2007, 169: 494-504

71 Thompson J N, Schwind C, Friberg M. Diversification of trait combinations in coevolving plant and insect lineages. Am Natist, 2017, 190: 171184 
72 Sun H Q, Li A, Ban W. Morphological variation and its adaptive significance for Changnienia amoena, an endangered orchid (in Chinese). Biodiv Sci, 2005, 13: 376-386 [孙海芹, 李昂, 班玮, 等. 濒危植物独花兰的形态变异及其适应意义. 生物多样性, 2005, 13: 376-386]

73 Medel R, Valiente A, Botto-Mahan C, et al. The influence of insects and hummingbirds on the geographical variation of the flower phenotype in Mimulus luteus. Ecography, 2007, 30: 812-818

74 Zhao Z G, Huang S Q. Differentiation of floral traits associated with pollinator preference in a generalist-pollinated herb, Trollius ranunculoides (Ranunculaceae). Int J Plant Sci, 2013, 174: 637-646

75 Kuriya S, Hattori M, Nagano Y, et al. Altitudinal flower size variation correlates with local pollinator size in a bumblebee-pollinated herb, Prunella vulgaris L. (Lamiaceae). J Evol Biol, 2015, 28: 1761-1769

76 Zhang F, Hui C, Pauw A. Adaptive divergence in Darwin's race: How coevolution can generate trait diversity in a pollination system. Evolution, 2013, 67: 548-560

77 Steiner K E, Whitehead V B. The association between oil-producing flowers and oil-collecting bees in the Drakensberg of southern Africa. Monogr Syst Bot Mo Bot Gard, 1988, 25: 259-277

78 Steiner K E, Whitehead V B. Pollinator adaptation to oil-secreting flowers - Rediviva and Diascia. Evolution, 1990, 44: 1701-1707

79 Bradshaw H D, Schemske D W. Allele substitution at a flower colour locus produces a pollinator shift in monkeyflowers. Nature, 2003, 426: 176178

80 Arnold S E J, Savolainen V, Chittka L. Flower colours along an alpine altitude gradient, seen through the eyes of fly and bee pollinators. Arthropod-Plant Interact, 2009, 3: 27-43

81 Koski M H, Ashman T L. An altitudinal cline in UV floral pattern corresponds with a behavioral change of a generalist pollinator assemblage. Ecology, 2015, 96: 3343-3353

82 Galen C, Newport M E A. Bumble bee behavior and selection on flower size in the sky pilot, Polemonium viscosum. Oecologia, 1987, 74: 20-23

83 Suinyuy T N, Donaldson J S, Johnson S D. Geographical matching of volatile signals and pollinator olfactory responses in a cycad brood-site mutualism. Proc R Soc B, 2015, 282: 20152053

84 Terry I, Walter G H, Moore C, et al. Odor-mediated push-pull pollination in cycads. Science, 2007, 318: 70

85 Suinyuy T N, Johnson S D. Geographic variation in cone volatiles and pollinators in the thermogenic African cycad Encephalartos ghellinckii Lem. Plant Biol J, 2018, 20: 579-590

86 Gowda V, Kress W J. A geographic mosaic of plant-pollinator interactions in the eastern caribbean islands. Biotropica, 2013, 45: 224-235

87 Ferreiro G, Baranzelli M C, Sérsic A N, et al. Patterns of phenotypic selection for oil and nectar in Monttea aphylla (Plantaginaceae) in a geographic mosaic of interactions with pollinators. Flora, 2017, 232: 47-55

88 Gervasi D D L, Schiestl F P. Real-time divergent evolution in plants driven by pollinators. Nat Commun, 2017, 8: 14691

89 Stankowski S, Sobel J M, Streisfeld M A. Geographic cline analysis as a tool for studying genome-wide variation: A case study of pollinatormediated divergence in a monkeyflower. Mol Ecol, 2017, 26: 107-122

90 Turner T L, Hahn M W, Nuzhdin S V. Genomic islands of speciation in Anopheles gambiae. PLoS Biol, 2005, 3: e285

91 Twyford A D, Friedman J. Adaptive divergence in the monkey flower Mimulus guttatus is maintained by a chromosomal inversion. Evolution, 2015, 69: 1476-1486

92 Seehausen O, Butlin R K, Keller I, et al. Genomics and the origin of species. Nat Rev Genet, 2014, 15: 176-192

93 Szymura J M, Barton N H. Genetic analysis of a hybrid zone between the fire-bellied toads, Bombina bombina and B. variegata, near Cracow in southern Poland. Evolution, 1986, 40: 1141-1159

94 Gay L, Crochet P A, Bell D A, et al. Comparing clines on molecular and phenotypic traits in hybrid zones: A window on tension zone models. Evolution, 2008, 62: 2789-2806

95 Bridle J R, Baird S J E, Butlin R K. Spatial structure and habitat variation in a grasshopper hybrid zone. Evolution, 2001, 55: 1832-1843

96 Stankowski S. Ecological speciation in an island snail: Evidence for the parallel evolution of a novel ecotype and maintenance by ecologically dependent postzygotic isolation. Mol Ecol, 2013, 22: 2726-2741 


\title{
Geographic mosaic theory of coevolution in plant and pollinator interaction: Process, evidence, prospect
}

\author{
Xiaoyue Wang ${ }^{1}$, Xiaoxin Tang ${ }^{1}$, Zeyu Tong ${ }^{2} \&$ Shuangquan Huang ${ }^{2 *}$ \\ ${ }^{1}$ Key Laboratory of National Forestry and Grassland Administration on Biodiversity Conservation in Karst Mountainous Areas of Southwestern China, \\ Key Laboratory of Plant Physiology and Developmental Regulation, School of Life Science, Guizhou Normal University, Guiyang 550025, China; \\ ${ }^{2}$ Institute of Evolution and Ecology, School of Life Sciences, Central China Normal University, Wuhan 430079, China \\ *Corresponding author, Email: hsq@mail.ccnu.edu.cn
}

Coevolution refers to evolutionary changes in the traits of two or more interacting species caused by reciprocal natural selection. Geographic mosaic theory of coevolution (GMC) proposes that the dynamics of coevolution between pairs or group of species often occur at different geographic scales. There are three hypotheses on the coevolutionary process. (1) Different evolutionary interaction trajectories among populations are likely to generate a selection mosaic. (2) A mixture of coevolutionary hotspots and coldspots. Hot spots are the subset of communities in which much of the coevolutionary change occurs and coldspots refer to areas where coevolutionary selection hardly occurs or completely does not occur. (3) There is a continual population remixing of the range of coevolving traits, resulting from the selection mosaic, coevolutionary hotspots, gene flow, random genetic drift, and local extinction of subpopulations. Studies of GMC between plants and pollinators indicate that shifts of effective pollinators among different geographic populations may cause divergence in floral traits (i.e., pollination ecotype). Changes of pollinator assemblages or species components have been illustrated coevolving with floral morphology or reward among populations from different altitudes or habitats. Here, recent case studies of GMC between plants and pollinators are grouped into five categories: Floral morphology and pollinator components, corolla tube/nectar spur and pollinator feeding structure, floral color, floral scents, floral rewards and pollinator assemblages. Floral tube or nectar spur length is positively related to pollinator body structures, such as the proboscis and leg length. The adaptation of flower color and pollinator vision provides a series of examples for the GMC. With the increase of altitude, flower color changed from blue and ultraviolet blue adapted to bee vision to blue-green and green adapted to fly vision. Recent study indicated that the difference in cycad odor components related to a shift of beetle species in different regions, suggesting a potential coevolutionary relationship between flower odor and pollinators. Studies showed that where bees foraged more nectar, flowers secreted more nectar, suggesting that floral reward amounts and types coevolve with pollinators among different geographic populations. An examination of GMC in plant-pollinator interactions involves three steps in general: (1) Detection of the relationship between floral traits and pollinator shift or body structure. (2) Transplanting experiments to detect differences in seed set between native phenotypes and transplanted phenotypes. (3) Single pollinator visit experiment to detect pollen output differences between native and transplanted phenotypes. Experimental evolutionary biology not only can test whether floral variation is related to pollinator shifts, but also make people aware of the impact of the reduction or loss of pollinators on the evolutionary consequences. To illustrate GMC between plants and pollinators, it is essential to isolate the evolutionary changes in traits caused by biotic factors or abiotic factors in future. It would be highly appreciated if genome scans and analysis are used in further studies to explore the genome-wide patterns of GMC between plants and pollinators.

coevolution, the geographic mosaic theory of coevolution, pollination ecotype, diversification, plant-pollinator interaction

doi: $10.1360 / \mathrm{N} 972018-01213$ 